\title{
THE STRESS-AND-STRAIN STATE OF THE SOUTH-EASTERN PART OF THE SKYBA AND BORYSLAV-POKUTTYA NAPPES OF THE UKRAINIAN CARPATHIANS
}

\author{
I. M. Bubniak ${ }^{1}$, Yu. M. Vikhot ${ }^{1}$, M. V. Nakapelyukh ${ }^{2}$ \\ ${ }^{1}$ Ivan Franko National University of Lviv, Department of Geology, Lviv, Ukraine \\ ${ }^{2}$ S.I. Subbotin Institute of Geophysics, NAS of Ukraine, Kyiv, Ukraine
}

\begin{abstract}
The article presents results of field studies and interpretation of tectonophysical data from profiles in the valleys of Bystritsa Nadvornyanskaya, Prut, Pistynka (the right-side tributary of the Prut river), Belyi and Chernyi Cheremosh, and Seret rivers. The stress fields reconstructed from different groups of joints and slickensides in flysch and molasse sediments of the Skyba and Boryslav-Pokuttya nappes are analyzed.

A combination of the structural-paragenesis and kinematic analysis methods provided for determination of deformation modes, their sequences, and average azimuth values of orientations of the principal axes of regional paleostress fields $\left(\sigma_{1}, \sigma_{2}\right.$, $\sigma_{3}$ ) which were manifested through the Alpine stage of the Ukrainian Carpathians development.

The paleostress fields were reconstructed for the south-eastern part of the Skyba nappe of the Ukrainian Carpathians and the Boryslav-Pokuttya nappe of the Carpathian foretrough. The article describes similarities and differences in the stress-andstrain states, specific features of the paleostress fields, and the ratio of joints in different groups (oblique and perpendicular to the rock layers) and slickensides in the area under study.
\end{abstract}

Key words: Ukrainian Carpathians, Skyba nappe, Boryslav-Pokuttya nappe, evolution of palaeostress fields, deformation mode, joint, slickenside.

Recommended by Yu.L. Rebetsky

Citation: Bubniak I.M., Vikhot Yu.M., Nakapelyukh M.V. 2013. The stress-and-strain state of the south-eastern part of the Skyba and Boryslav-Pokuttya nappes of the Ukrainian Carpathians. Geodynamics \& Tectonophysics 4 (3), 313-326. doi:10.5800/GT-2013-4-3-0103.

\section{НАПРЯЖЕННО-ДЕФОРМИРОВАННОЕ СОСТОЯНИЕ ЮГО-ВОСТОЧНОЙ ЧАСТИ СКИБОВОГО И БОРИСЛАВСКО-ПОКУТСКОГО ПОКРОВОВ УКРАИНСКИХ КАРПАТ}

\author{
И. Н. Бубняк ${ }^{1}$, Ю. М. Вихоть ${ }^{1}$, М. В. Накапелюх ${ }^{2}$ \\ ${ }^{1}$ Львовский национальный университет им. Ивана Франко, геологический факультет, Львов, Украина \\ ${ }^{2}$ Институт геофизики им. С.И. Субботина НАН Украины, Киев, Украина
}

Аннотация: В статье изложены новые результаты полевых работ и интерпретации материалов тектонофизических исследований, проведенных по поперечным пересечениям в бассейнах рек Быстрица Надворнянская, Прут, Пистынка (правый приток р. Прут), Белый и Черный Черемош, Серет. Проанализированы поля напряжений, реконструированные по разным группам трещин и зеркалам скольжения во флишевых и молассовых отложениях Скибового и Бориславско-Покутского покровов. 
Комплексное применение структурно-парагенетического и кинематического методов позволило определить деформационные режимы с указанием их последовательности и средних значений азимутов ориентации главных осей региональных полей палеонапряжений $\left(\sigma_{1}, \sigma_{2}, \sigma_{3}\right)$, существовавших здесь в течение всего альпийского этапа развития Украинских Карпат.

Реконструированы поля палеонапряжений юго-восточной части Скибового покрова Украинских Карпат и Бориславско-Покутского покрова Предкарпатского передового прогиба. Выявлено сходство и различие напряженно-деформированного состояния, особенности полей палеонапряжений, соотношение различных групп трещин (кососекущих и нормальносекущих относительно слоев пород) и зеркал скольжения.

Ключевые слова: Украинские Карпаты, Скибовый покров, Бориславско-Покутский покров, эволюция полей палеонапряжений, деформационный режим, трещина, зеркало скольжения.

\section{1. ВВЕДЕНИЕ}

Изучение напряженно-деформированного состояния является ключевым инструментом для решения ряда проблем тектоники и геодинамики регионов со сложным геологическим строением. Поля напряжений помогают наложить ограничения при построении моделей деформации складчато-надвиговых поясов.

Актуальным на сегодня является изучение систем трещиноватости и напряженно-деформированного состояния на участках существующих месторождений нефти и газа. Современные поля напряжений должны учитываться при прогнозировании оползневых явлений в различных тектоно-геоморфологических обстановках.

Достижения последних лет в изучении разломной тектоники позволяют дополнить, а в некоторых случаях и по-иному рассмотреть вопросы геодинамики складчато-надвиговой тектоники Карпатского орогена. Проведению качественных тектонофизических исследований также способствует широкое использование информационных технологий на всех этапах - от сбора данных до их обработки и интерпретации. Результаты тектонофизических исследований начали широко применяться для построения сбалансированных разрезов в складчато-надвиговых областях [Nemcok et al., 2006].

Задача статьи - показать напряженно-деформированное состояние юго-восточной части Скибового и Бориславско-Покутского покровов на различных этапах их развития по результатам изучения и интерпретации трещин и зеркал скольжения, их использования в структурной геологии и тектонике. Полевые работы были проведены в 2012 г. в Черновецкой и ИваноФранковской областях.

\section{2. ПРЕДЫДУЩИЕ РАБОТЫ}

В последние годы тектонофизические исследования в Украинских Карпатах приобретают систематический характер. Первые масштабные полевые тектонофизи- ческие работы проведены в 1992-1994 гг. [Aronsky et al., 1995a, 1995b, 1995c]. Исследования, в которых использовались приемы полевой тектонофизики, также проводили отдельные группы ученых, например [ $\mathrm{Zu}$ chiewicz et al., 1997; Bubniak et al., 2001]. В то же время западные ученые выполнили огромные объемы тектонофизических исследований в районах Южных, Румынских Восточных, Западных Карпат и Паннонского бассейна [Ciulavu et al., 2000; Matenco et al., 1997; Matenco, Bertotti, 2000; Ratschbacher et al., 1993a, 1993b; Nemcok, 1993; Nemcok et al., 1998; Fodor et al., 1999; Konon, 2001]. Они получили важные материалы о напряженно-деформированном состоянии этих регионов, используя новые технологии обработки и интерпретации полевых данных. Были сформулированы новые концепции, описывающие историю развития регионов АЛЬКАПА (Альпы, Карпаты, Паннония), Тиссия и Дакия.

С 2006 г. началось целенаправленное изучение отдельных участков и мезоструктур украинского сектора Восточных Карпат группой львовских и киевских геологов [Bubniak et al., 2007; Vikhot, Bubniak, 2011; Vikhot et al., 2011; Gintov et al., 2011, 2013; Bubniak, Vikhot, 2012], а также проводится моделирование формирования мезоструктур (складок) и построение сбалансированных разрезов [Nakapelyukh et al., 2011].

\section{3. ГЕОЛОГИЧЕСКОЕ ПОЛОЖЕНИЕ}

Украинские Карпаты являются частью Восточных Карпат, входящих в состав Европейских Альпид. Они состоят из тектонических покровов, формирующих древнюю аккреционную призму. Украинские Карпаты традиционно делятся на Внешние и Внутренние. Деление выполнено на основе времени завершающих этапов складчато-надвиговых процессов в них. Исследуемая территория охватывает фронтальную часть Внешних Карпат. Складчато-надвиговые процессы здесь происходили в ранне-позднемиоценовое время.

В статье использовано тектоническое деление Украинских Карпат в соответствии с работой [Shlapinsky, 


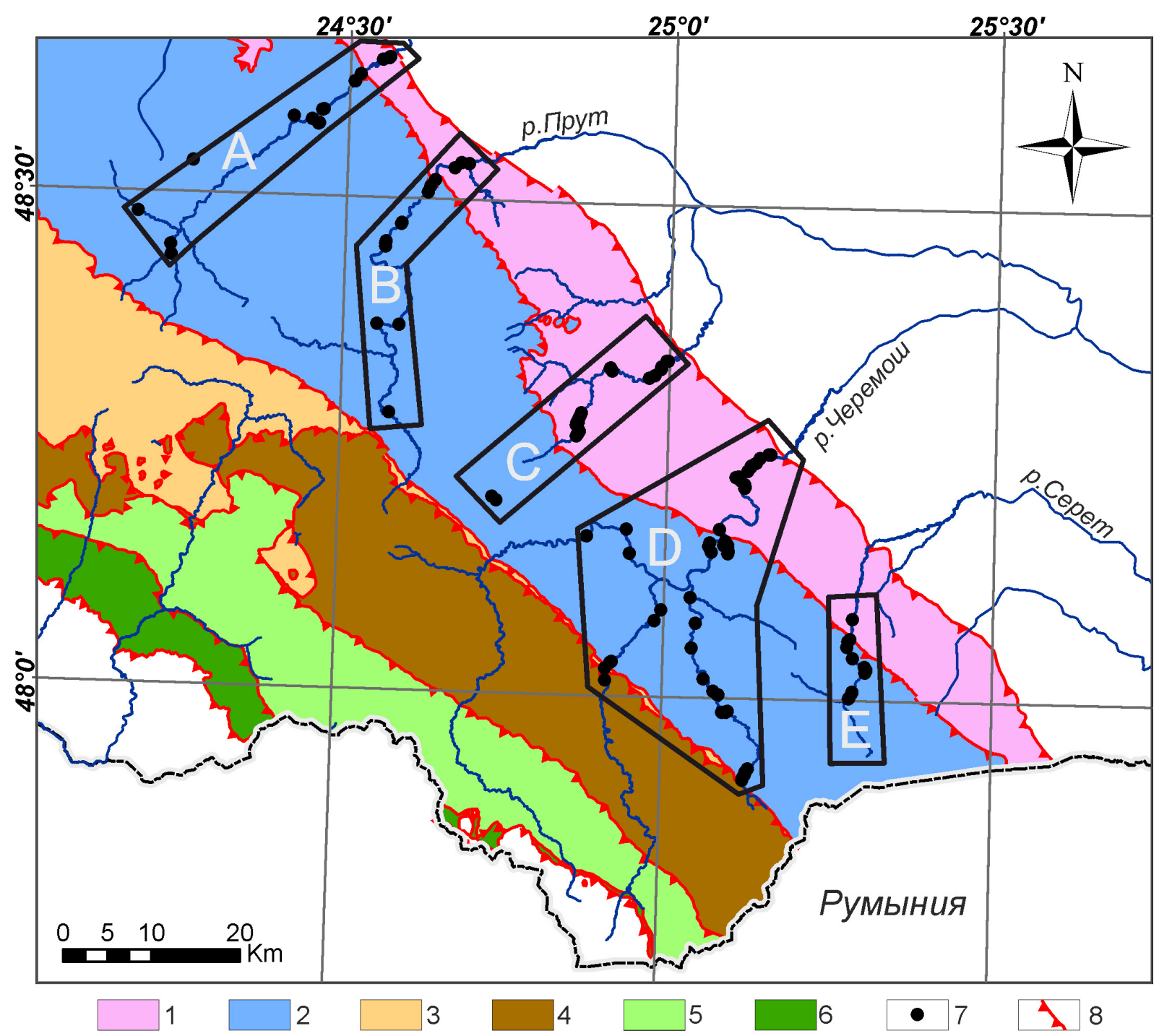

Рис. 1. Тектоническая схема юго-восточной части Восточных Украинских Карпат с районами исследования (покровы: 1 Бориславско-Покутский, 2 - Скибовый, 3 - Кросненский, 4 - Дуклянско-Черногорский, 5 - Буркутский, 6 - Раховский; 7 районы исследований с точками наблюдения - бассейны рек: А - Быстрица Надворнянская, В - Прут, С - Пистынка, D Черемош, Е - Серет; 8 - основные надвиги).

Fig. 1. The tectonic scheme of the south-eastern part of the Eastern Ukrainian Carpathians, showing areas under study (nappes: 1 Boryslav-Pokuttya, 2 - Skiba, 3 - Krosna, 4 - Duklya-Chernogorsky, 5 - Burkut, 6 - Rakhovsky; 7 - studied areas and observation sites - river valleys: A - Bystritsa Nadvornyanskaya, B - Prut, C - Pistynka, D - Cheremosh, E - Seret; 8 - main thrusts).

2012]. Согласно этой тектонической схеме они делятся на Предкарпатский передовой прогиб и Украинские Внешние Карпаты. Предкарпатский прогиб составляют Билче-Волыцкая зона (Внешняя зона), Самборский и Борислав-Покутский покровы (Внутренняя зона). Украинские Внешние Карпаты делятся на покровы: Скибовый, Кросненский, Дуклянско-Черногорский, Буркутский, Раховский (рис. 1).

Скибовый покров надвинут (вместе с Внутренней зоной Предкарпатского прогиба) на Восточноевропейскую платформу и ее эпиорогенное каледонское и герцинское обрамление. Он состоит из серии структур высшего порядка - скиб, которые надвинуты в северовосточном направлении друг на друга с большой ам- плитудой. В состав покрова входят восемь скиб (с юго-запада на северо-восток): Славская, Рожанки, Зелемянки, Мальмастанская, Парашки, Сколевская, Оривская, Береговая. Скибы, в свою очередь, деформированы чешуеобразными надвигами (близкими по литологическому составу чешуями) и складчатостью. Фронтальные части скиб, как правило, представлены более древними породами, а тыльные - более молодыми.

Стратиграфический интервал района исследований охватывает отложения от нижнего мела по нижний миоцен в северной части покрова и от верхнего мела по нижний миоцен в южной части. Это турбидитовые (флишевые) образования и молассовые комплексы, 
которые на основе возрастных и литологических особенностей объединяются в ряд стратиграфических подразделений: спаская ( $\left.\mathrm{K}_{1} \mathrm{sp}\right)$, стрийская $\left(\mathrm{K}_{2} \mathrm{P}_{1} \mathrm{str}\right)$, ямненская свиты $\left(\mathrm{P}_{1} \mathrm{jm}\right)$, эоцен нерасчлененный $\left(\mathrm{P}_{2}\right)$, менилитовая $\left(\mathrm{P}_{3} \mathrm{mnl}\right)$, поляницкая $\left(\mathrm{N}_{1} \mathrm{pl}\right)$, воротищенская $\left(\mathrm{N}_{1} \mathrm{vrt}_{1}\right)$, стебницкая $\left(\mathrm{N}_{1} \mathrm{st}\right)$, добротивская $\left(\mathrm{N}_{1} \mathrm{db}\right)$ свиты.

По современным представлениям ороген Украинских Карпат является древней аккреционной призмой, образовавшейся в результате сокращения седиментационного пространства и прогрессивного перемещения осадочных образований на океанической или утоненной континентальной коре. Наиболее крупные перемещения происходили по черносланцевым породам мелового возраста и по менилитовым сланцам олигоцена. Складчатость мигрировала с юго-запада на северо-восток. Величина сокращения бассейна в миоцене, по данным палинспастических реконструкций [Roure et al., 1993], составила 130 км, по другим реконструкциям [Oszczypko, 2006; Oszczypko, Oszczypko-Clowes, 2009] только миоценовое сокращение Внешних Западных Карпат составило 150-200 км.

Образование аккреционной призмы стало результатом субдукции под блоки Алькапа, Тиссия и Дакия на миоценовом этапе развития региона [Patalakha et al., 2003; Bubniak, 2005; Gonchar, 2007]. По [Konon, 2001], перемещение Украинских Внешних Карпат было связано с откатом эоцен-олигоценовой зоны субдукции в северо-восточном направлении в миоцене. По [Fodor et al., 1999], формирование складчатого пояса Западных, Восточных и Южных Карпат связано с мезоальпийской конвергенцией Европейской и Адриатической микроплит и блоков земной коры в среднем миоцене раннем олигоцене. Начиная с позднего миоцена на деформации Восточных Карпат основное влияние оказывала конвергенция Африканской и Евроазиатской плит. Сложное напряженно-деформированное состояние всего Карпато-Паннонского мегаблока авторы объясняют автономными перемещениями и поворотами блоков Алькапа, Тиссия и Дакия.

\section{4. МЕТОДЫ ИССЛЕДОВАНИЙ}

Тектонофизические исследования выполнялись посредством комплексного использования структурнопарагенетического и кинематического методов. Эффективность такого комплексирования была доказана при изучении многих горно-складчатых регионов, в том числе Горного Крыма и Карпат [Aronsky et al., 1995a, 1995b, 1995c; Gintov, Murovskaya, 2000a, 2000b; Gintov, 2005].

Структурно-парагенетический метод основан на изучении парагенетических связей мезотрещин, трещин и складок, характера и геометрических параметров складчатости. Трещиноватость горных пород в Украинских Карпатах изучается давно как при геоло- госъемочных работах, так и в научных целях. Ее исследование приносило и приносит хорошие результаты в нефтяной геологии при поисках месторождений нефти, газа и озокерита, изучении коллекторов, проницаемости пород для флюидов, путей миграции углеводородов и др. Однако использование трещин при изучении тектонических полей напряжений началось в Украинских Карпатах только в 90-х годах прошлого столетия. Было показано, что в сложных в тектоническом отношении районах, таких как Карпаты и Горный Крым, трещинообразование связано с региональными полями напряжений и, следовательно, изучение в натурных условиях структурных парагенезисов трещин, установленных в лабораторных тектонофизических экспериментах, позволяет восстанавливать такие поля. Для этого использовалась общая тектонофизическая модель деформационной структуры горного массива I-II уровней глубинности [Gintov, 2005].

Восстановление тектонических полей напряжений кинематическим методом по зеркалам скольжения имеет свои особенности и позволяет получать такие кинематические параметры, как соотношение величин главных нормальных напряжений $\sigma_{1}, \sigma_{2}$ и $\sigma_{3}$, а также относительную величину касательного напряжения в точке наблюдений. Однако зеркала скольжения в древних комплексах, как правило, не сохраняются, а в молодых слабодеформированных породах не образуются, поэтому возраст деформаций и полей напряжений, полученный при использовании кинематического метода, отражает достаточно узкий интервал геологического времени - средние и поздние этапы тектогене3a.

Обработка и интерпретация материалов замеров трещиноватости выполнялись на основе известных принципов выделения парагенетически связанных сколов и трещин отрыва (L-L', R-R', L-R', L'-R; L', R'-T и т.д.) [Gintov, Isai, 1986] для I-II уровней глубинности. Для обработки замеров использовалась программа StereoNett 2.46 Ж. Дайстера (Институт геологии университета г. Бохум, Германия), которая позволяет восстанавливать первоначальную ориентацию нормальносекущих (другое название - касательных) трещин в пласте путем приведения его в горизонтальное положение.

Материалы замеров борозд и штрихов на зеркалах скольжения обрабатывались и интерпретировались с помощью программы Win-Tensor 2.2.0 [Devlaux, Sperner, 2003], являющейся на настоящий момент одной из наиболее технологичных программ интерпретации в кинематическом методе. Предложенный авторами программы алгоритм позволяет определять наиболее оптимальное положение главных осей $\sigma_{1}, \sigma_{2}, \sigma_{3}$ и их стереографические координаты (в рассматриваемых исследованиях сжатие принято положительным и $\left.\sigma_{1} \geq \sigma_{2} \geq \sigma_{3}\right)$, а также соотношение величин главных нормальных напряжений $\mathrm{R}=\left(\sigma_{2}-\sigma_{3}\right) /\left(\sigma_{1}-\sigma_{3}\right)$. Этот коэффициент играет такую же роль, как и более употребляе- 
мый у нас коэффициент Лоде-Надаи $\mu_{\sigma}=\left(2 \sigma_{2}-\sigma_{1}-\right.$ $\left.\sigma_{3}\right) /\left(\sigma_{1}-\sigma_{3}\right)$, и используется для определения типа напряженного состояния, а также для районирования полей напряжений по величине $\mu_{\sigma}$ или R.

При интерпретации полевых данных структурнопарагенетическим методом в первую очередь обращалось внимание на поля напряжений, полученные по нормальносекущим трещинам, которые образуются в еще горизонтально залегающей толще либо как планетарная трещиноватость, либо как трещиноватость, связанная с самым ранним полем тектонических напряжений. Первая отличается от второй тем, что оси $\sigma_{1}$ и $\sigma_{3}$ ориентированы вдоль современных параллелей и меридианов, часто сменяют друг друга в силу инверсии полей напряжений, связанной с неравномерной скоростью вращения Земли [Gintov, 2001] (как известно, в мезокайнозое положение оси вращения планеты по отношению к материкам мало отличалось от современного). Тектонические поля напряжений могли характеризоваться другой ориентацией главных осей в горизонтальной плоскости.

Трещины, падающие субвертикально в наклонных слоях и, как правило, не имеющие штрихов скольжения, являются наиболее поздними, поэтому поля напряжений, восстановленные по их парагенезисам, относились к самым молодым.

Наклонные трещины, остающиеся наклонными и после выполаживания напластования, относились к неопределенному классу и интерпретировались как соскладчатые. Поля напряжений, восстановленные по ним, сопоставлялись с результатом интерпретации зеркал скольжения, после чего делался вывод об их возрасте (если это было возможно).

Зеркала скольжения образуются при интенсивных тектонических движениях, то есть поля напряжений, восстановленные по ним, моложе полей, определенных по нормальносекущей трещиноватости, но древнее полей, восстановленных по молодым субвертикальным трещинам. Более точно возраст таких полей определялся по возрасту слоев, в которых образовались зеркала, времени тектонических движений согласно геологическим данным и ряду других признаков, которые изучались в полевых условиях.

В каждой точке наблюдений было сделано от 30 до 150 замеров плоскостей трещин и зеркал скольжения.

\section{5. РЕЗУЛЬТАТЫ ИССЛЕДОВАНИЙ}

Основные исследования выполнены на границе Украинских Внешних Карпат и Предкарпатского передового прогиба. Полевые исследования были проведены в юго-восточной части Скибового и Бориславско-Покутского покровов. Изучение мезоструктур - трещин, зеркал скольжения (рис. 2) - выполнено в обнажениях по пяти поперечным профилям вдоль долин рек Быстрица Надворнянская, Прут, Пистынка, Черемош, Се- рет. Общее количество точек наблюдений составляет 115, в них выполнено около 6000 замеров плоскостей трещин и 550 зеркал скольжения (см. рис. 1).

Бассейн р. Быстрица Надворнянская. Район исследований пересекает Скибовый и Бориславско-Покутский покровы в центральной части Украинских Карпат. Пересечение протяженностью более 50 км охватывает скибы Береговую, Оривскую и Парашки в районе сел Климпуши, Быстрица, Максимец, Зеленая, Пасечная, Быткив. В двенадцати обнажениях палеогеновых пород от ямненской $\left(\mathrm{P}_{1 j} \mathrm{~m}\right)$ до верховинской $\left(\mathrm{P}_{3} \mathrm{vr}\right)$ свит выполнено около 1000 измерений плоскостей трещин, а в отложениях эоцена $\left(\mathrm{P}_{2}\right)$ - 95 зеркал скольжения. Результаты интерпретации полей напряжений структурно-парагенетическим и кинематическим методами представлены на рис. 3.

Около 70 \% трещин на участке являются нормальносекущими и по ним реконструированы несколько древних полей напряжений, в основном с субгоризонтальными главными осями $\sigma_{1}, \sigma_{3}$ (рис. $3, a-8, e$ ). Кинематическим методом реконструированы четыре поля палеонапряжений (рис. 3, 2, д, ж, з). Предварительное разделение зеркал скольжения было выполнено в поле на основе кинематических признаков и соотношения разных их типов. Наиболее молодыми оказались зеркала, характеризующие сбросы.

В отложениях эоцена $\mathrm{P}_{2}$ и олигоцена $\mathrm{P}_{3}$ установлены древние поля: $\sigma_{1}-1 \angle 7^{\circ}, \sigma_{3}-270 \angle 2^{\circ}, \mathrm{R}-0.62$; $\sigma_{1}-269 \angle 2^{\circ}, \sigma_{3}-359 \angle 2^{\circ}, \mathrm{R}-0.75$ (рис. 3, а, б). Эти поля отражают, скорее всего, этап развития самой ранней трещиноватости.

Поле напряжений с осями $\sigma_{1}$, ориентированными по северо-восточно-юго-западным азимутам: $\sigma_{1}-59 \angle 1^{\circ}$, $\sigma_{3}-329 \angle 3^{\circ}, \mathrm{R}-0.5$ (рис. 3, в), фиксируется во всем разрезе в еще горизонтально залегавших флишевых толщах осадков. Ориентация оси $\sigma_{1}$ соответствует общекарпатскому (для Украинских Карпат) сжатию, но поскольку режим сдвиговый и плоскость $\sigma_{1} \sigma_{3}$ горизонтальна, можно сделать вывод, что такие поля напряжений отражают самое начало орогенического процесса, когда сжатие уже наступило, но отложения олигоцена залегали еще горизонтально.

Из всех замеренных зеркал скольжения в отложениях эоцена наибольшее количество связано с взбросовым деформационным режимом и полями напряжений $\sigma_{1}-239 \angle 10^{\circ}, \sigma_{3}-340 \angle 45^{\circ}, \mathrm{R}=0.4 ; \sigma_{1}-021 \angle 1^{\circ}, \sigma_{3}-$ $113 \angle 61^{\circ}, \mathrm{R}=0.25$ (рис. 3, г, $\partial$ ). Это поле отражает фазу общекарпатского сжатия в северо-восточном направлении, сопровождавшуюся надвигами и шарьяжами. При этом важно отметить, что зеркала скольжения наблюдались в основном на субгоризонтальных или пологопадающих плоскостях.

Далее следует поле напряжений сдвигового типа: $\sigma_{1}$ - $127 \angle 3^{\circ}, \sigma_{3}-037 \angle 3^{\circ}, \mathrm{R}=0.5$, определенное по молодой трещиноватости (рис. 3,e). Это поле отражает сдвиговый деформационный режим при сжатии, ориентированном вдоль Украинских Карпат, то есть попе- 


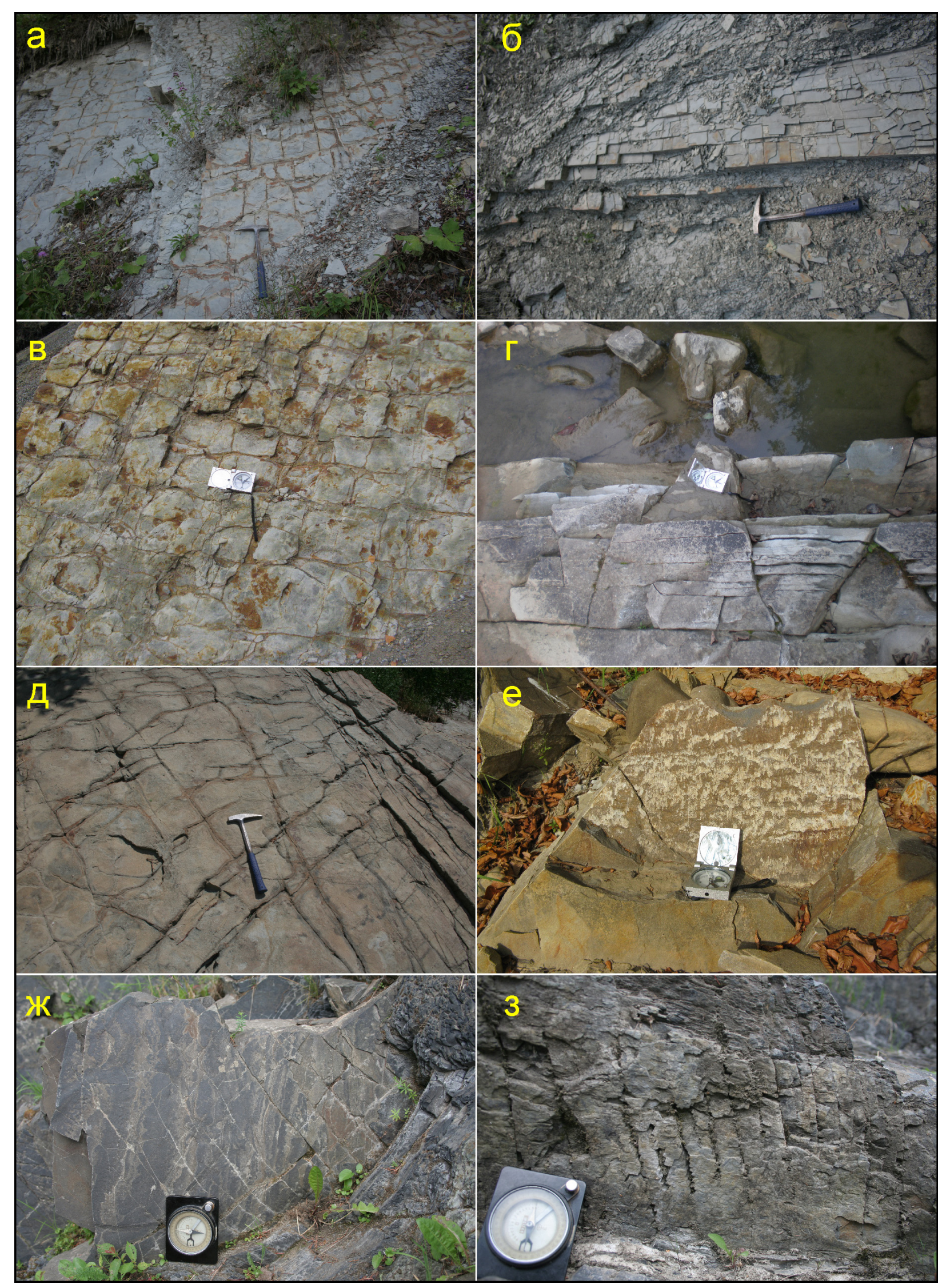

| Рис. 2. Трещины $(a-\partial, ж, 3)$ и зеркала скольжения $(e)$ в разных возрастных отложениях исследуемого района.

Fig. 2. Joints $(a-\partial, \ldots, 3)$ and slickensides $(e)$ in sediments of various ages in the studied area. 


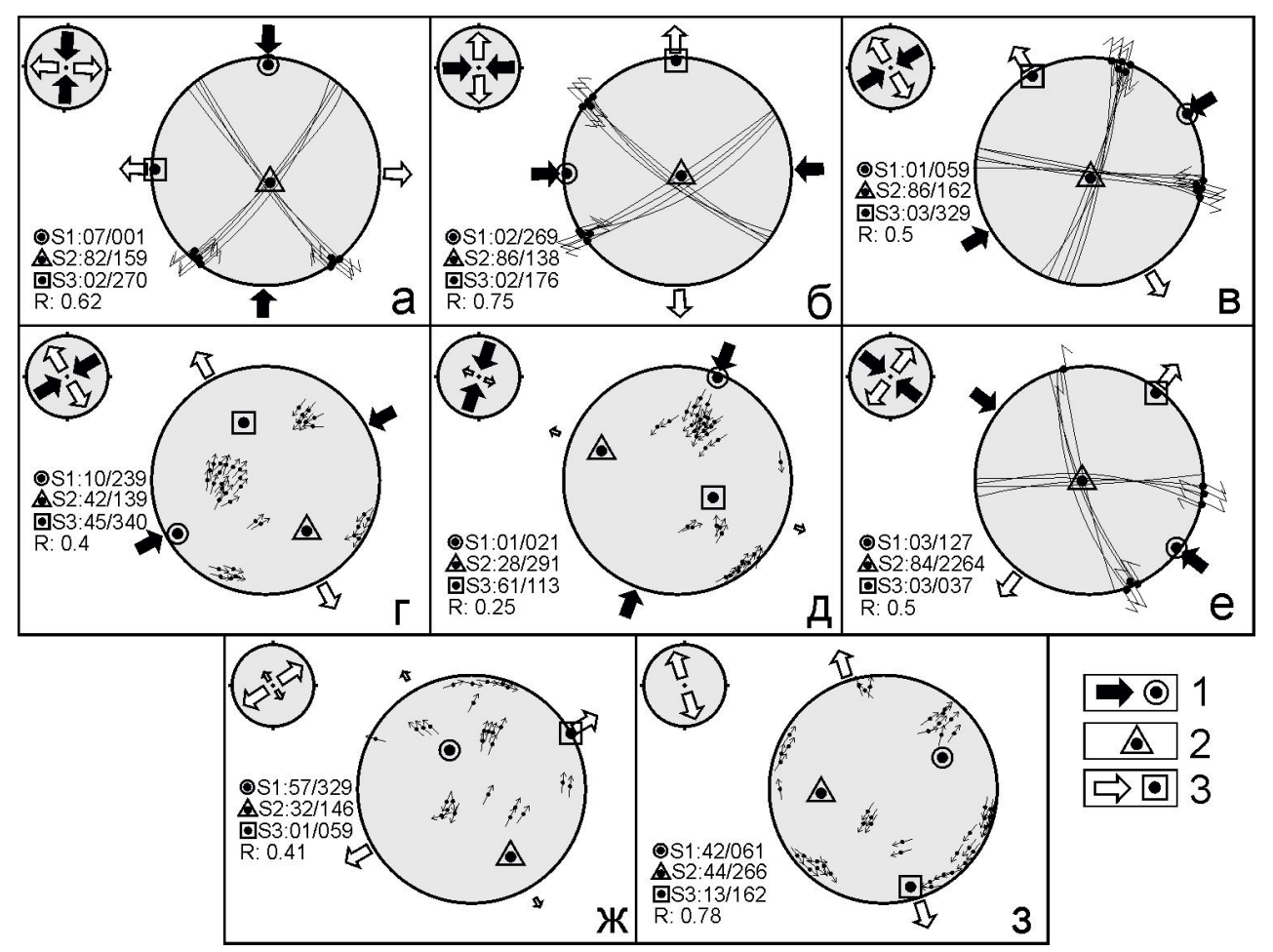

Рис. 3. Результаты интерпретации тектонофизических данных по материалам изучения трещиноватости и зеркал скольжения в бассейне р. Быстрица Надворнянская.

Главные оси и их направления: 1 - сжатия, 2 - промежуточная, 3 - растяжения.

Fig. 3. Tectonophysical data interpretation results based on information collected from studies of fracturing and slickensides in the watershed area of the Bystritsa Nadvornyanskaya river.

Principal stress axes and their directions: 1 - compression, 2 - transitional, 3 - extension.

речно к генеральному направлению перемещения скиб и покровов.

Не менее представительны сбросовые деформационные режимы, отраженные в полях: $\sigma_{1}-329 \angle 57^{\circ}, \sigma_{3}-$ $59 \angle 1^{\circ}, \mathrm{R}=0.41 ; \sigma_{1}-61 \angle 42^{\circ}, \sigma_{3}-162 \angle 13^{\circ}, \mathrm{R}=0.78$ (рис. 3, ж, 3). Сбросовые поля, по кинематическим признакам, наиболее молодые. Они возникли в конце процесса складко- и надвигообразования и, скорее всего, наблюдаются до сих пор.

Бассейн р. Прут. Район исследований пересекает Скибовый и Бориславско-Покутский покровы юго-восточнее предыдущего участка. Он охватывает верхнее и среднее течение р. Прут до устья р. Ославы в следующих населенных пунктах: с. Татарив, с. Мыкуличин, г. Яремче, с. Заречье, г. Делятин, с. Добротов. Результаты с реконструированными полями палеонапряжений на этом участке исследования показаны на рис. 4.

Структурно-парагенетическим методом определены четыре поля напряжений. Все они отображают сдвиговые деформационные режимы (рис. 4, $a, 6$, в, д). Два поля тектонических напряжений: $\sigma_{1}-1 \angle 7^{\circ}, \sigma_{3}-$ $270 \angle 2^{\circ}, \mathrm{R}=0.62$ (рис. $4, a$ ); $\sigma_{1}-271 \angle 2^{\circ}, \sigma_{3}-2 \angle 5^{\circ}$, $\mathrm{R}=0.5$ (рис. 4, б) являются самими древними. Поле напряжений $\sigma_{1}-224 \angle 3^{\circ}, \sigma_{3}-314 \angle 1^{\circ}, \mathrm{R}=0.75$ (рис. 4, в) отражает начало общекарпатского сжатия в конце палеогена еще до процессов складко- и надвигообразования.

Далее следует поле взбросового деформационного режима, определенное кинематическим методом: $\sigma_{1}$ $36 \angle 17^{\circ}, \sigma_{3}-283 \angle 52^{\circ}, \mathrm{R}=0.38$ (рис. 4, г). Оно представлено наибольшим количеством замеров, связано с главным горообразовательным процессом в Украинских Карпатах и отражает общекарпатское сжатие, сопровождавшееся взбросами, надвигами, шарьяжами, правыми и левыми сдвигами, что хорошо видно и по элементам залегания зеркал скольжения.

Поле напряжений сдвигового типа, реконструированное по молодым парагенезисам трещин $\sigma_{1}$ $337 \angle 8^{\circ}, \sigma_{3}-246 \angle 4^{\circ}, \mathrm{R}=0.75$ (рис. $4, \partial$ ), характеризуется ориентацией оси сжатия субпараллельно простиранию Украинских Карпат.

Поле напряжений $\sigma_{1}-196 \angle 68^{\circ}, \sigma_{3}-67 \angle 14^{\circ}, \mathrm{R}=0.57$ (рис. $4, e$ ), определенное кинематическим методом, отражает интенсивный сбросовый деформационный режим. На основе кинематических признаков это поле является самым молодым.

Бассейн р. Пистынка. Тектонофизические исследования выполнены в пределах населенных пунктов 


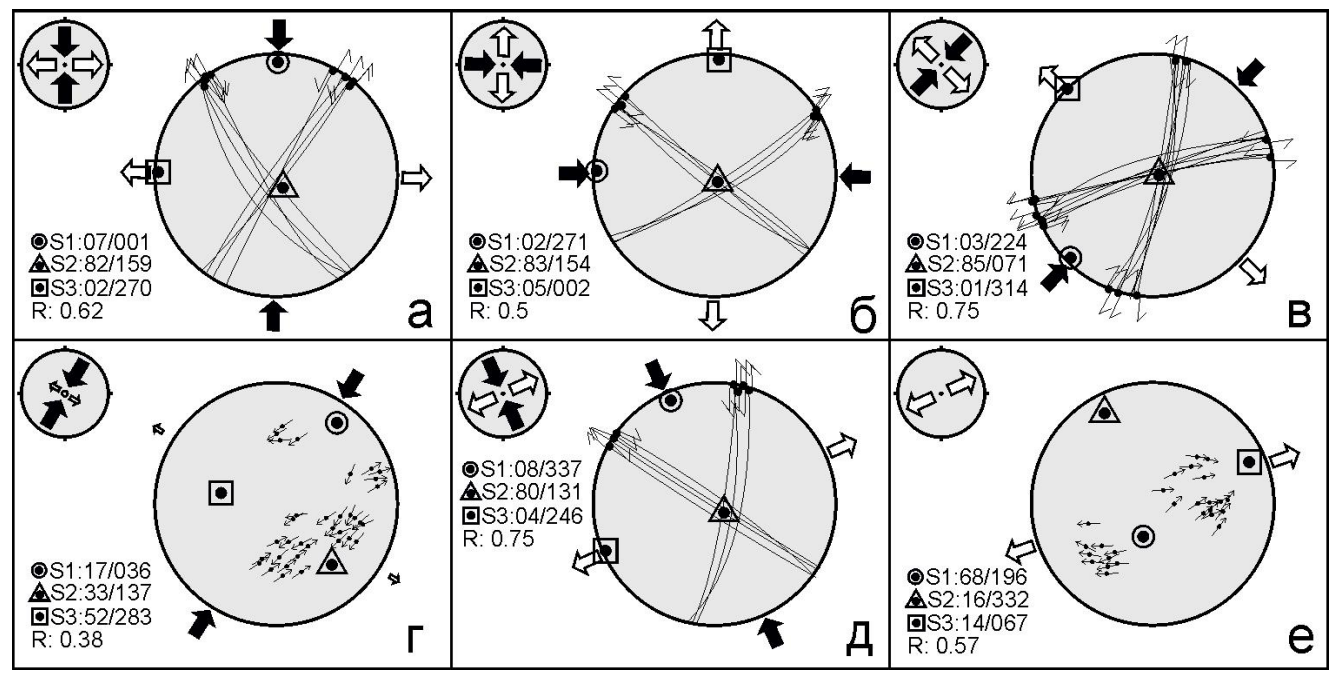

Рис. 4. Результаты структурно-парагенетического и кинематического анализа в бассейне р. Прут.

Fig. 4. Results of structural-paragenesis and kinematic analyses of data on the watershed of the Prut river.

Кривополье, Шепот, Брустуров, Прокурава, Шешоры, Пистынь в долине одноименной р. Пистынка, являющейся правым притоком р. Прут.

Основные исследования проведены в БориславскоПокутском покрове. Часть этого покрова на юго-востоке от долины реки Пистынка получила название «Покутско-Буковинские складки». Эта крупная структурная единица данного покрова рассматривается всеми исследователями как его приподнятая складчатая основа, выведенная на поверхность. Максимальная ширина складок составляет около 16-17 км в бассейне рек Пистынка и Рыбница. В юго-восточном направлении выходы складок постепенно сужаются до 3.5 км на границе с Румынией.

Результаты интерпретации тектонофизических данных по этому участку показаны на рис. 5. Три поля напряжений определены структурно-парагенетическим (рис. $5, a-8)$ и три поля - кинематическим (рис. 5 , 2-e) методом.

Все поля, реконструированные по парагенезисам трещин, отображают сдвиговые деформационные режимы. Первые два: $\sigma_{1}-354 \angle 4^{\circ}, \sigma_{3}-84 \angle 3^{\circ}, \mathrm{R}=0.69$ (рис. $5, a) ; \sigma_{1}-93 \angle 2^{\circ}, \sigma_{3}-3 \angle 1^{\circ}, \mathrm{R}=0.75$ (рис. 5, б), характеризуют древние поля тектонических напряжений. Третье поле: $\sigma_{1}-73 \angle 8^{\circ}, \sigma_{3}-339 \angle 24^{\circ}, \mathrm{R}=0.69$ (рис. 5, в), как и в ранее рассмотренных пересечениях, отражает, скорее всего, начало общекарпатского сжатия в конце палеогена еще до процессов складкообразования.

Три поля тектонических напряжений по материалам изучения зеркал скольжения отображают взбросовый деформационный режим: $\sigma_{1}-21 \angle 2^{\circ}, \sigma_{3}-$ $288 \angle 62^{\circ}, \mathrm{R}=0.36$ (рис. 5, г); и два сбросовых: $\sigma_{1}-$ $185 \angle 55^{\circ}, \sigma_{3}-58 \angle 22^{\circ}, \mathrm{R}=0.45$ (рис. $5, \partial$ ); $\sigma_{1}-105 \angle 51^{\circ}$, $\sigma_{3}-285 \angle 38^{\circ}, \mathrm{R}=0.62$ (рис. $5, e$ ). Большинство векторов подвижек по разрывам отражает фазу общекарпатского сжатия, сопровождавшуюся надвигами, шарьяжами, а также правыми и левыми сдвигами. Два других сбросовых поля являются самыми молодыми. Они могли сопровождать процесс горообразования или сформировались позже как отражение разрушения горной цепи Украинских Карпат.

Бассейн р. Черемош. Пересечение полностью охватывает Бориславско-Покутский и Скибовый покровы, а также частично Кросненский и фронтальную часть Дуклянско-Чорногорского. Изучение мезоструктур выполнялось в долинах рек Черный Черемош, Белый Черемош, Черемош и Путила в населенных пунктах Дихтинец, Путила, Яблуница, Устерики, Верховина, Розтоки, Тюдов, Углы, Вижница. На этом участке выполнено 2000 замеров трещин и 200 зеркал скольжения. Исследования выполнены во всех отложениях, составляющих стратиграфический разрез Украинских Внешних Карпат.

Результаты комплексного определения палеонапряжений на этом участке показаны на рис. 6. Структурно-парагенетическим методом изучения нормальносекущих и косых трещин определены три древних и одно молодое поле палеонапряжений (рис. $6, a-8, \partial$ ). Все эти поля отражают сдвиговые деформационные режимы. Кинематическим методом реконструированы четыре поля, которые образовались в основном во время и после процессов складко- и надвигообразования.

По парагенезисам трещин, как видим, определены два древних инверсионных поля планетарных напряжений: субмеридиональное сжатие $-\sigma_{1}-358 \angle 13^{\circ}, \sigma_{3}-$ $266 \angle 1^{\circ}, \mathrm{R}=0.62$ (рис. $6, a$ ); сменяется субширотным $\sigma_{1}-273 \angle 5^{\circ}, \sigma_{3}-4 \angle 4^{\circ}, \mathrm{R}=0.60$ (рис. 6, б).

Далее следует поле тектонических напряжений, ко- 


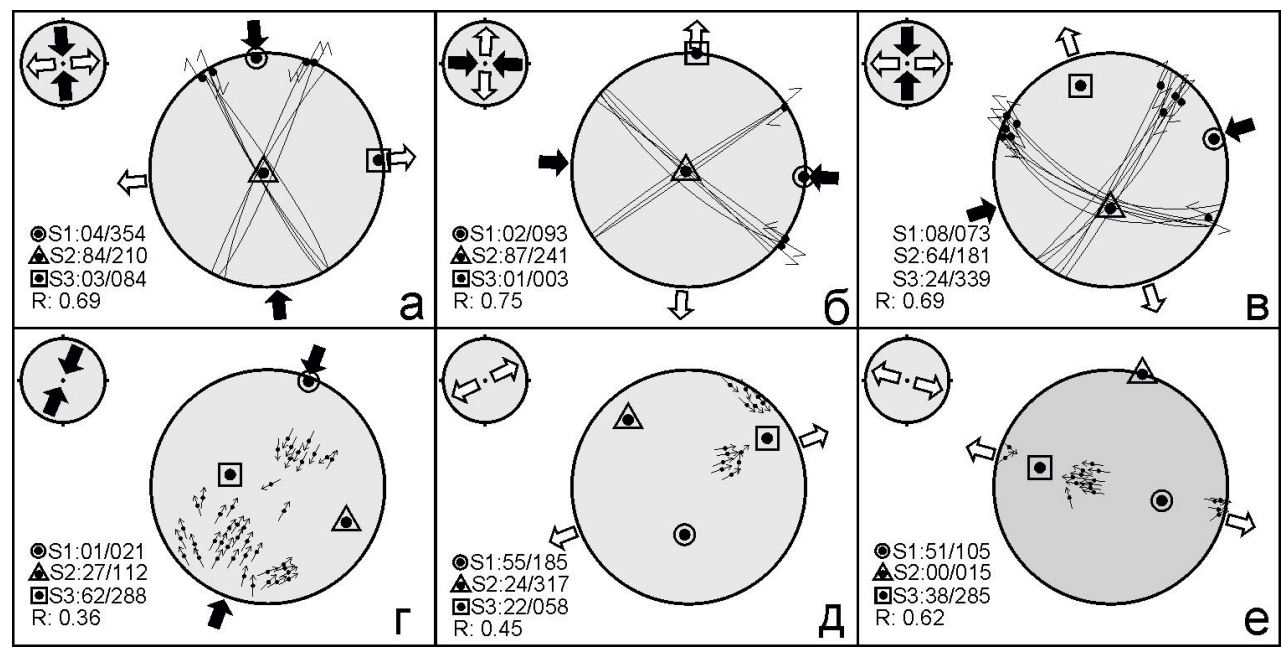

Рис. 5. Результаты интерпретации тектонофизических данных по материалам изучения зеркал скольжения и парагенезисов трещин в бассейне р. Пистынка.

Fig. 5. Tectonophysical data interpretation results based on information collected from studies of fracturing and slickensides in the watershed area of the Pistynka river.

торое возникло еще до процессов складкообразования. Оно отображает сдвиговый деформационный режим с осью сжатия общекарпатского направления: $\sigma_{1}$ $22 \angle 15^{\circ}, \sigma_{3}-292 \angle 1^{\circ}, \mathrm{R}=0.60$ (рис. 6, в). Это поле характеризует начало северо-восточного сжатия, зафиксированное в отложениях олигоцена, залегавших еще горизонтально. Это поле отражает, как и на предыдущих участках, самое начало орогенического процесса.

Большинство векторов смещения на зеркалах скольжения отражают напряженное состояние общекарпатского сжатия, сопровождавшееся взбросами, надвигами, шарьяжами, правыми и левыми сдвигами. Тектоническое поле, в котором происходил основной процесс складко- и надвигообразования с перемещением материала с юго-запада на северо-восток, имеет следующие главные оси: $\sigma_{1}-21 \angle 1^{\circ}, \sigma_{3}-288 \angle 62^{\circ}$, $\mathrm{R}=0.36$ (рис. 6, г). Среди полей напряжений, восстановленных кинематическим методом, оно самое раннее и, как на предыдущих участках, является наиболее представительным.

После основного процесса общекарпатского сжатия зафиксированы поля с осью сжатия, ориентированной перпендикулярно к генеральному направлению перемещения скиб и покровов Украинских Внешних Карпат: $\sigma_{1}-334 \angle 7^{\circ}, \quad \sigma_{3}-242 \angle 17^{\circ}, \mathrm{R}=0.58$ (рис. 6, $\partial$ ), $\sigma_{1}-$ $310 \angle 17^{\circ}, \sigma_{3}-217 \angle 9^{\circ}, \mathrm{R}=0.69$ (рис. $6, e$ ). Эти поля напряжений обусловлены, скорее всего, тектоническими процессами в Южных и Западных Карпатах, для которых субмеридиональное сжатие является определяющим.

Наиболее молодыми, по кинематическим признакам и соотношению разных типов зеркал в толщах горных пород, оказались зеркала, характеризующие два типа сбросов $\sigma_{1}-17 \angle 51^{\circ}, \sigma_{3}-200 \angle 38^{\circ}, \mathrm{R}=0.57$ (рис. 6, ж); $\sigma_{1}-220 \angle 40^{\circ}, \sigma_{3}-122 \angle 8^{\circ}, \mathrm{R}=0.36$ (рис.
6, з). Сбросы отвечают очень молодому, даже современному, полю напряжений, сопровождающему оползневые и другие процессы разрушения гор.

Аналогичные сбросовые поля, как отмечалось выше, были получены и в пересечениях рек Быстрица Надворнянская, Прут, Пистынка.

Бассейн р. Серет. Этот участок является самым южным поперечным пересечением района исследований. Он охватывает обнажения вдоль долины р. Серет у населенных пунктов Долишний Шепот, Лопушна, Берегомет. Результаты изучения трещин и зеркал скольжения по правому и левому берегам этой реки показаны на рис. 7.

По результатам комплексного анализа выделены следующие поля напряжений и соответствующие им деформационные режимы. Первые два поля палеонапряжений сдвигового деформационного режима, как и на предыдущих участках, являются самими древними: $\sigma_{1}-178 \angle 7^{\circ}, \sigma_{3}-87 \angle 2^{\circ}, \mathrm{R}=0.69$ (рис. 7, $a$ ); $\sigma_{1}-$ $266 \angle 1^{\circ}, \sigma_{3}-176 \angle 2^{\circ}, \mathrm{R}=0.54$ (рис. 7, б). Третье сдвиговое поле $-\sigma_{1}-210 \angle 16^{\circ}, \sigma_{3}-319 \angle 53^{\circ}, \mathrm{R}=0.64-$ (рис. 7, в) - отражает начало горообразовательного процесса в Украинских Карпатах. Эти три поля палеонапряжений реконструированы по доскладчатым трещинам.

По большинству зеркал скольжения реконструирован взбросовый деформационный режим. Поле напряжений: $\sigma_{1}-216 \angle 16^{\circ}, \sigma_{3}-329 \angle 53^{\circ}, \mathrm{R}=0.33$ (рис. 7, г) характеризует перемещения горных масс на северовосток во время основных складчато-надвиговых процессов.

Еще одно сдвиговое поле напряжений определено по молодым парагенезисам трещин: $\sigma_{1}-290 \angle 3^{\circ}, \sigma_{3}-$ $201 \angle 5^{\circ}, \mathrm{R}=0.62$ (рис. $7, \partial$ ). Такие поля установлены и 


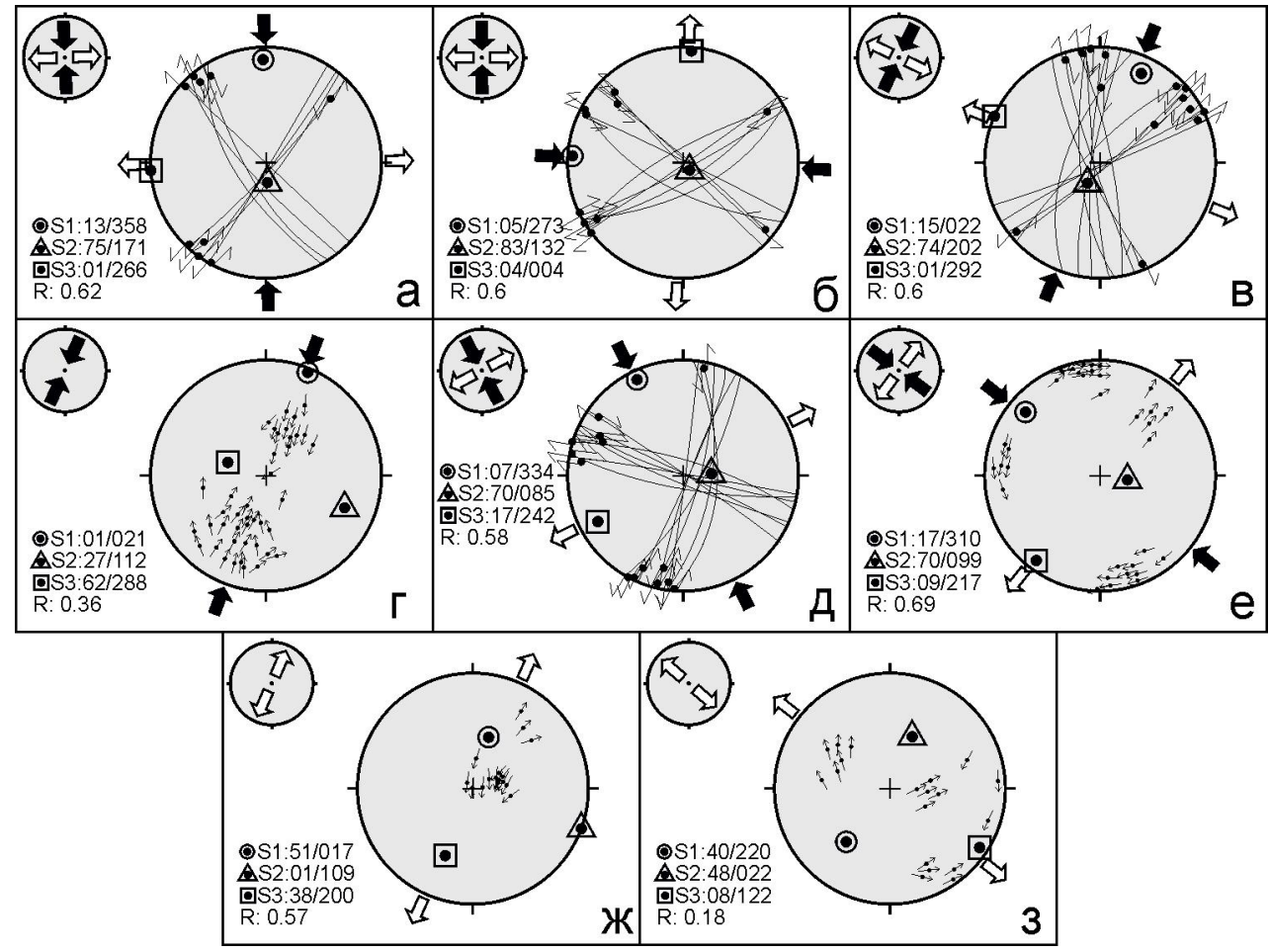

| Рис. 6. Результаты интерпретации структурно-парагенетического и кинематического анализа в долине р. Черемош.

I Fig. 6. Results of structural-paragenesis and kinematic analyses of data on the valley of the Cheremosh river.

на предыдущих участках.

Наиболее молодым является поле напряжений сбросового типа: $\sigma_{1}-196 \angle 50^{\circ}, \sigma_{3}-48 \angle 34^{\circ}, \mathrm{R}=0.47$ (рис. 7, e). В этом поле сформировалось основное количество сбросов в Бориславско-Покутском покрове на данном участке. Оно отражает интенсивное растяжение в юго-западном направлении, наступившее после главного складчато-надвигового процесса Украинских Карпат.

\section{6. ОБСУЖДЕНИЕ}

Поля палеонапряжений, полученные на пяти участках исследований, расклассифицированы по трем этапам - доскладчатому, складчато-надвиговому и послескладчатому - на основании критериев, приведенных в методической части. Синхронизация времени деформации, азимутов ориентации главных осей полей напряжений $\left(\sigma_{1}, \sigma_{3}\right)$ и деформационных режимов позволяет с достаточной определенностью говорить о тектонических силах в земной коре, действовавших на всех трех этапах формирования Скибового и Бориславско-Покутского покровов Украинских Карпат.

На доскладчатом этапе в районе исследований преобладали тангенциальные силы - плоскость $\sigma_{1} \sigma_{3}$ была практически горизонтальной (сдвиговый деформационный режим). Уже на этом этапе, когда еще деформации были небольшими, началось общекарпатское сжатие земной коры (азимуты $\left.\sigma_{1}-202-253^{\circ}\right)$.

Однако, как только стала формироваться складчатонадвиговая структура Украинских Карпат в миоценовое время, ось растяжения $\sigma_{3}$ приняла субвертикальное положение. Взбросовый деформационный режим по пяти пересечениям Скибового и Бориславско-Покутского покровов определен по максимальному количеству векторов подвижек. В работе [Gintov et al., 2011] было показано, что в Скибовом покрове одновременно с надвигами формировались сдвиги, отражающие неравномерное перемещение разных скиб и покровов, а также взбросовые поля напряжений с антикарпатской и субмеридиональной ориентацией оси сжатия.

По сводным кинематическим данным общее усредненное положение оси сжатия $\sigma_{1}$ этого деформационного режима определено как $215 \angle 9^{\circ}$. Ранее при детальном изучении северо-западной части Скибового покрова [Gintov et al., 2011] были определены оси сжатия: $\sigma_{1}-47 \angle 5^{\circ}$ (по кинематическим данным) и $\sigma_{1}-$ $235 \angle 11^{\circ}$ (по комплексным данным). Полученное положение оси сжатия достаточно хорошо согласуется с материалами изучения Румынских Восточных Карпат [Matenco et al., 1997], по которым она имеет ориентацию $241 \angle 15 \pm 15^{\circ}$.

В послескладчатый этап в основном происходили сбросовые деформации, при которых ось растяжения $\sigma_{3}$ ориентирована как в северо-восточном, так и в северо-западном направлении. Сбросовые подвижки, 


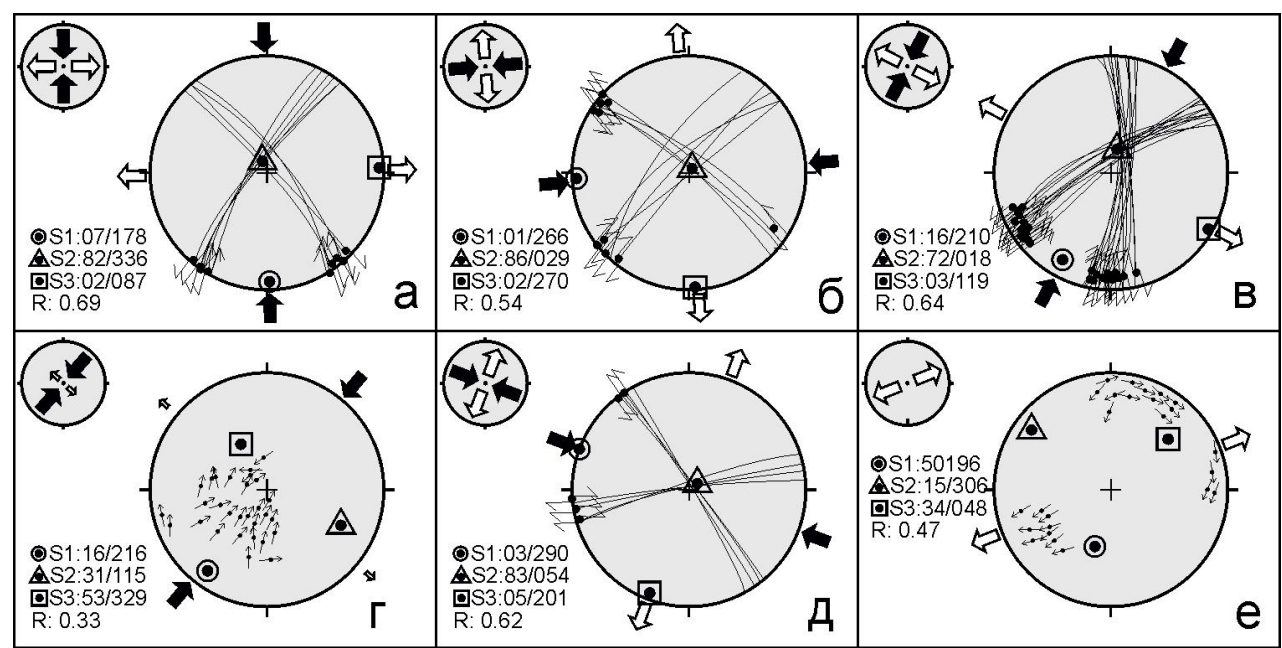

Рис. 7. Результаты интерпретации тектонофизических данных по материалам изучения трещиноватости и зеркал скольжения в бассейне р. Серет.

Fig. 7. Tectonophysical data interpretation results based on information collected from studies of fracturing and slickensides in the watershed area of the Seret river.

продолжающиеся и в настоящее время, происходили в основном в тех же направлениях, что и надвиговые, и были связаны с прерывистым характером перемещения скиб и покровов и с оползневыми процессами в их фронтальных частях.

Предложенный сценарий эволюции полей напряжений согласуется с региональными геодинамическими моделями для Альпийско-Карпатского региона [Roure et al., 1993; Fodor et al., 1999; Matenco et al., 1997; Cloetingh et al., 2006]. Это в основном касается также и внешних частей Карпатского орогена, где на небольшой территории сосуществуют режимы сжатия во внешних частях орогена и растяжения в форланде Украинских Карпат. Такое сочетание режимов, на наш взгляд, обусловлено развитием отступающей континентальной зоны субдукции в неогеновый период.

Анализируя напряженно-деформированные состояния по изученным пересечениям, можно обнаружить их некоторые особенности для юго-восточной части Скибового и Бориславско-Покутского покровов. В этой части Украинских Карпат много складок, зеркал скольжения. При обработке и интерпретации трещиноватости было установлено, что более 85-90 \% трещин на участках Пистынка, Черемош, Серет являются нормальносекущими к напластованию, а в обнажениях долин р. Быстрица Надворнянская и Прут зафиксировано около 50-65 \% нормальносекущих трещин и заметно возрастает количество кососекущих. Такое распределение разных типов трещин может быть связано с глубинным строением района. Залегание фундамента к северо-западу от р. Прут отмечается на глубине 13-14 км, тогда как к юго-востоку (пересечение рек Пистынка, Черемош, Серет) - 6-8 км. Эти участки названы, соответственно, Гуцульским и Бойковским блоками [Shlapinsky, 2012].

Характер этих блоков так же хорошо объясняет распространение месторождений углеводородов [Shlapinsky, 2012]. Основные месторождения расположены в Бориславско-Покутском покрове на Бойковском блоке, который перекрыт мощным флишевым и молассовым комплексом, а с переходом на Гуцульский блок месторождения углеводородов во флишевых и молассовых отложениях исчезают. Разведано только одно относительно крупное месторождение - Лопушнянское, но оно расположено в палеозойском чехле платформы.

Сравнение трещинной структуры и полученных тектонофизических данных позволяет предположить, что в исследованном районе после сильного сжатия, особенно в Бориславско-Покутском покрове, наступило сильное растяжение. О преобладании растяжения в Бориславско-Покутском покрове свидетельствуют также результаты изучения тектонического опускания во внешней зоне Предкарпатского прогиба [Dolenko et al., 1976]. Растяжение обусловило формирование густой системы открытых трещин, но из-за особенностей глубинного геологического строения не способствовало накоплению углеводородов во флишевом и молассовом комплексах юго-восточной части Скибового и Бориславско-Покутского покровов.

\section{7. Выводы}

Полевые исследования с детальным тектонофизическим изучением мезоструктур - трещин и зеркал скольжения - в юго-восточной части Скибового и Бориславско-Покутского покровов по пяти поперечным 
пересечениям позволили восстановить региональные поля тектонических напряжений.

Комплексное использование структурно-парагенетического и кинематического анализа дало возможность определить последовательность главных деформационных процессов. Выявлены особенности полей палеонапряжений и характер напряженно-деформированного состояния юго-восточной части Скибового и Бориславско-Покутского покровов.

Отсутствие месторождений углеводородов в юговосточной части обоих покровов обусловлено, скорее всего, их растяжением после надвигового процесса и связанным с этим формированием густой системы открытых трещин, которые не способствовали здесь аккумуляции углеводородов.

\section{8. БЛАГОДАРНОСТИ}

Авторы выражают благодарность главному научному сотруднику отдела тектонофизики Института геофизики имени С.И. Субботина НАН Украины профессору О.Б. Гинтову за помощь в организации полевых исследований, обсуждение работы и замечания.

\section{9. ЛИТЕРАТУРА}

Aronsky A.A., Belichenko P.V., Gintov O.B., Murovskaya A.V., 1995a. Kinematic parameters of deformation of the upper crustal horizons of the Ukrainian Carpathians in the Miocene-Pleistocene (according to tectonophysical data). Geofizicheskiy Zhurnal 17 (3), 58-68 (in Russian) [Аронский А.А., Беличенко П.В., Гинтов О.Б., Муровская А.В. Кинематические параметры деформирования верхних горизонтов земной коры Украинских Карпат в миоцен-плейстоценовую эпоху (по тектонофизическим данным) // Геофизический журнал. 1995а. Т. 17. № 3. С. 58-68].

Aronsky A.A., Belichenko P.V., Gintov O.B., Murovskaya A.V., 1995b. Kinematic parameters of deformation of the upper crustal horizons of the Ukrainian Carpathians in the Miocene-Pleistocene (according to tectonophysical data). Geofizicheskiy Zhurnal 17 (5), 11-19 (in Russian) [Аронский А.А., Беличенко П.В., Гинтов О.Б., Муровская А.В. Кинематические параметры деформирования верхних горизонтов земной коры Украинских Карпат в миоцен-плейстоценовую эпоху (по тектонофизическим данным) // Геофизический журнал. 1995b. T. 17. № 5. С. 11-19].

Aronsky A.A., Belichenko P.V., Gintov O.B., Murovskaya A.V., 1995c. Kinematic parameters of deformation of the upper crustal horizons of the Ukrainian Carpathians in the Miocene-Pleistocene (according to tectonophysical data). Geofizicheskiy Zhurnal 17 (6), 43-57 (in Russian) [Аронский А.А., Беличенко П.В., Гинтов О.Б., Муровская А.В. Кинематические параметры деформирования верхних горизонтов земной коры Украинских Карпат в миоцен-плейстоценовую эпоху (по тектонофизическим данным) // Геофизический журнал. 1995с. Т. 17. № 6. С. 43-57].

Bubniak I.M., 2005. Tectonics of the junction zone between the East European platform and the Ukrainian Carpathians. Synopsis of PhD Thesis (Candidate degree in geology). Institute of Geological Sciences, NAS of Ukraine, Kyiv, 21 p. (in Ukrainian) [Бубняк И.M. Тектоніка зони зчленування Східно-Європейської платформи та Українських Карпат: автореф. дис. на здобуття наук. ступеня канд. геол. наук. Київ, України: Інститут геологічних наук НАН, 2005 21 c.].

Bubniak I., Bubniak A., Kilyn I., Popp I., 2001. Structural and sedimentological studies of the Dobrotiv deposits of the Carpathian foretrough (Nadvirny district). In: Proceedings of the Shevchenko Scientific Society. Geological Collection (5), 8493 (in Ukrainian) [Бубняк I., Бубняк А., Кілин I., Попn I. Структурно-седиментологічні дослідження добротівських відкладів Передкарпатського прогину (район Надвірної) // Праці наукового товариства імені Шевченка. Геологічний збірник. 2000. V. 5. С. 84-93].

Bubniak I., Bubniak A., Vikhot Y., Spilnyk R., 2007. Rock jointing of the flysch complex of the Ukrainian Carpathians between the Opir and Oryava rivers, and its tectonic significance. Geodynamics 1 (6), 4-10 (in Ukrainian) [Бубняк I., Бубняк А., Віхоть Ю., Спільник Р. Тріщинуватість гірських порід флішового комплексу Українських Карпат в межиріччі Опору та Оряви та її тектонічне значення // Геодинаміка. 2007. Т. 6. № 1. С. 4-10].

Bubniak I., Vikhot Y., 2012. Tectonophysic research of flysh deposits of the Zelemianka thrust in the valleys of Kobilets and Yagystiv rivers. In: Proceedings of the Shevchenko Scientific Society. Geological Collection XXX, 119-130 (in Ukrainian) [Бубняк I., Віхоть Ю. Тектонофізичні дослідження флішових відкладів скиби Зелем'янки в долинах струмків Кобилець та Ягистів // Праці НТШ: Геологічний збірник. 2012. Т. ХХХ. С. 119-130].

Ciulavu D., Dinu C., Szakacs A., Dordea D., 2000. Neogene kinematics of the Transylvanian basin (Romania). American Association of Petroleum Geologists 84 (10), 1589-1615. http://dx.doi.org/10.1306/8626BF0B-173B-11D7-8645000102 C1865D.

Cloetingh S., Bada G., Matenco L., Lankreijer A., Horvath F., Dinu C., 2006. Modes of basin (de)formation, lithospheric strength and vertical motions in the Pannonian-Carpathian system: inferences from thermo-mechanical modeling. Geological Society, London, Memoirs 32, 207-221. http://dx.doi.org/10.1144/GSL.MEM.2006.032.01.12.

Devlaux D., Sperner B., 2003. New aspects of tectonic stress inversion with reference to the TENSOR program. Geological Society, London, Special Publications 212, 75-100. http://dx.doi.org/10.1144/GSL.SP.2003.212.01.06.

Dolenko G.N., Boychevskaya L.N., Kilyn I.V., 1976. Fault Tectonics of the Ukrainian Carpathian and Trans-Carpathian Foretroughs and Its Impact on the Distribution of Oil and Gas Deposits. Naukova Dumka, Kiev, 126 p. (in Russian) [Доленко Г.Н., Бойчевская Л.Т., Килын И.В. Разломная тектоника Предкарпатского и Закарпатского прогибов и ее влияние на распределение залежей нефти и газа. Киев: Наукова думка, 1976. 126 с.].

Fodor L., Csontos L., Bada G., Györfi I., Benkovics L., 1999. Tertiary tectonic evolution of the Pannonian basin system and 
neighbouring orogens: a new synthesis of paleostress data. Geological Society, London, Special Publication 156, 295334.

Gintov O.B., 2001. Planetary deformations of the Earth's crust, rotation of the Earth, and movements of the lithospheric plates. Geofizicheskiy Zhurnal 33 (4), 69-82 (in Russian) [Гинтов О.Б. Планетарные деформации земной коры, ротация Земли и движение литосферных плит // Геофизический журнал. 2001. Т. 23. № 4. С. 69-82].

Gintov O.B., 2005. Field Tectonophysics and Its Application in Studies of the Earth's Crust Deformation in Ukraine. Phenix, Kiev, 572 p. (in Russian) [Гинтов О.Б. Полевая тектонофизика и ее применение при изучении деформаций земной коры Украины. Киев: Феникс, 2005. 572 с.].

Gintov O.B., Bubniak I.M., Bubniak A.M., Vikhot Yu.M., Mychak S.V., Nakapelyukh M.V., 2013. The stress-and-strain state and the dynamics of the allochthon part of the Ukrainian Carpathian foretrough in relation to oil-and-gas-bearing capacities (according to tectonophysical data). Geofizicheskiy Zhurnal 35 (1), 75-87 (in Russian) [Гинтов О.Б., Бубняк И.Н., Бубняк А.Н., Вихоть Ю.М., Мычак С.В., Накапелюх М.В. Напряженно-деформированное состояние и динамика аллохтонной части Предкарпатского прогиба в связи с нефтегазоносностью (по тектонофизическим данным) // Геофизический журнал. 2013. Т. 35. № 1. С. 75-87].

Gintov O.B., Bubniak I.M., Vikhot Yu.M., Murovskaya A.V., Nakapelyukh M.V., 2011. The evolution of the stress-and-strain state and the dynamics of the Skyba nappe of the Ukrainian Carpathians. Geofizicheskiy Zhurnal 33 (5), 17-34 (in Russian) [Гинтов О.Б., Бубняк И.Н., Вихоть Ю.М., Муровская А.В., Накапелюх М.В. Эволюция напряженно-деформированного состояния и динамика Скибового покрова Украинских Карпат // Геофизический журнал. 2011. Т. 33. № 5. C. 17-34].

Gintov O.B., Isai V.M., 1986. Methods of morphokinematical analysis of faults. Geofizicheskiy Zhurnal 8 (1), $53-61$ (in Russian) [Гинтов О.Б., Исай В.М. Методы морфокинематического анализа разломов // Геофизический журнал. 1986. T. 8. № 1. С. 53-61].

Gintov O.B., Murovskaya A.V., 2000a. Problems of the crustal dynamics of the Crimean Peninsula in the Meso-Cenozoic (tectonophysical aspect). Geofizicheskiy Zhurnal 22 (2), 39-60 (in Russian) [Гинтов О.Б., Муровская А.В. Проблемы динамики земной коры Крымского полуострова в мезо-кайнозое (тектонофизический аспект) // Геофизический журнал. 2000а. Т. 22. № 2. С. 39-60].

Gintov O.B., Murovskaya A.V., 2000b. Problems of the crustal dynamics of the Crimean Peninsula in the Meso-Cenozoic (tectonophysical aspect). Geofizicheskiy Zhurnal 22 (3), 39-49 (in Russian) [Гинтов О.Б., Муровская А.В. Проблемы динамики земной коры Крымского полуострова в мезо-кайнозое (тектонофизический аспект) // Геофизический журнал. 2000b. T. 22. № 3. С. 36-49].

Gonchar V.V., 2007. Rheological control of accretion and nappe styles of deformation and the state of stresses of the oversubduction orogene. Geofizicheskiy Zhurnal 29 (6), 116-137 (in Russian) [Гончар В.В. Реологический контроль аккреционного и покровного стилей деформирования и напряженное состояние надсубдукционного орогена // Геофизический журнал. 2007. Т. 29. № 6. С. 116-137].

Konon A., 2001. Tectonics of the Beskid Wyspowy Mountains (Outer Carpathians, Poland). Geological Quaterly 45 (2), 179-204.

Matenco L., Bertotti G., 2000. Tertiary tectonic evolution of the external East Carpathians (Romania). Tectonophysics 316 (3-4), 255-286. http://dx.doi.org/10.1016/S0040-1951(99)00261-9.

Matenco L., Bertotti G., Dinu C., Cloetingh S., 1997. Tertiary tectonic evolution of the external South Carpathians and the adjacent Moesian platform (Romania). Tectonics 16 (6), 896-911. http://dx.doi.org/10.1029/97TC01238.

Nakapelyukh M.V., Vikhot Yu.M., Bubniak I.M., 2011. The balanced cross-section of the Skyba nappe of the Ukrainian Carpathians, the Sukil river valley. In: Modern tectonophysics. Methods and results. Proceedings of the $2^{\text {nd }}$ Tectonophysical Youth Workshop, October 17-21, 2011. IPE, Moscow, V. 1, p. 187-190 (in Russian) [Накапелюх М.В., Вихоть Ю.М., Бубняк И.Н. Сбалансированный разрез Скибового покрова Украинских Карпат, долина реки Сукиль // Современная тектонофизика. Методы и результаты. Материалы Второй молодежной тектонофизической школы-семинара, 17-21 октября 2011. Москва: ИФ3, 2011. Т. 1. С. 187-190].

Nemcok M., 1993. Transition from convergence to escape: field evidence from the West Carpathians. Tectonophysics 217 (1-2), 117-142. http://dx.doi.org/10.1016/0040-1951(93)90207-Z.

Nemcok M., Hok J., Kovac P., Marko F., Coward M.P., Madaras J., Houghton J., Bezak V., 1998. Tertiary extension development and extension/compression interplay in the West Carpathians mountain belt. Tectonophysics 290 (1-2), 137167. http://dx.doi.org/10.1016/S0040-1951(98)00016-X.

Nemcok M., Pogácsás G., Pospišil L., 2006. Activity timing of the main tectonic systems in the Carpathian-Pannonian region in relation to the rollback destruction of the lithosphere. In: Golonka J., Picha F.J. (Eds.), The Carpathians and their foreland: geology and hydrocarbon resources. The AAPG, Tulsa, Oklahoma, USA, p. 743-766.

Oszczypko N., 2006. Late Jurassic-Miocene evolution of the Outer Carpathian fold-and thrust belt and its foredeep basin (Western Carpathians, Poland). Geological Quarterly 50 (1), 168-194.

Oszczypko N., Oszczypko-Clowes M., 2009. Stages in the Magura Basin: a case study of the Polish sector (Western Carpathians). Geodinamica Acta 22 (1-3), 83-100. http://dx.doi.org/10.3166/ga.22.83-100.

Patalakha E.I., Gonchar V.V., Senchenkov I.K., Chervinko O.P., 2003. Elements of the Carpathians Geodynamics. In: Forecast of Hydrocarbons and Seismic Hazards. EKMO, Kiev, 151 p. (in Russian) [Паталаха Е.И., Гончар В.В., Сенченков И.К., Червинко О.П. Элементы геодинамики Карпат // Прогноз УВ и сейсмоопасности. Киев: ЭКМО, 2003. 151 c.].

Ratschbacher L., Frisch W., Linzer H.G., Sperner B., Meschede M., Decker K., Nemcok M., Nemcok J., Grygar R., 1993a. 
The Pieniny Klippen Belt in the Western Carpathians of northeastern Slovakia: structural evidence for transpression. Tectonophysics 226 (1-4), 471-483. http://dx.doi.org/10.1016/0040-1951(93)90133-5.

Ratschbacher L., Linzer H. G., Moser F., Strusievicz R.O., Bedelean H., Har N., Mogos P.A., 1993b. Cretaceous to Miocene thrusting and wrenching along the central South Carpathians due to a corner effect during collision and orocline formation. Tectonics 12 (4), 855-873. http://dx.doi.org/10.1029/93TC00232.

Roure F., Roca E., Sassi W., 1993. The Neogene evolution of the Outer Carpathian flysch units (Poland, Ukraine and Romania): kinematics of a foreland / fold-and-thrust belt system. Sedimentary Geology 86 (1-2), 177-201. http://dx.doi.org/ 10.1016/0037-0738(93)90139-V.

Shlapinsky V.E., 2012. Some aspects of the Ukrainian Carpathian tectonics. In: Proceedings of the Shevchenko Scientific Society. Geological Collection XXX, 48-67 (in Ukrainian) [Шлапінський В.Є. Деякі питання тектоніки Українських Карпат // Праці наукового товариства імені Шевченка: Геологічний збірник. 2012. Т. ХХX. С. 48-67].

Vikhot Yu., Bubniak I., 2011. Stress fields in the flysh strata of the Orivska, Skolivska and Parashka thrusts (by researches in the basin of the Sukil river). Geodynamics 1 (10), 75-82 (in Ukrainian) [Віхоть Ю., Бубняк I. Поля напружень у флішовій товщі скиб Орівської, Сколівської та Парашки (за дослідженнями у басейні ріки Сукіль) // Геодинаміка. 2011. T. 10. № 1. C. 5-82].

Vikhot Yu.M., Bubniak I.M., Nakapelyukh M.V., 2011. Results of tectonophysical studies of flysh deposits of the Skyba nappe of the Ukrainian Carpathians in the valley of the Bystrytsia Nadvornianskaya river. Geological Journal, NAS of Ukraine (2), 72-80 (in Ukrainian) [Віхоть Ю.М., Бубняк I.М., Накапелюх М.В. Результати тектонофізичних досліджень флішової товщі Скибового покриву Українських Карпат у долині р. Бистриця Надвірнянська // Геолічний журнал. 2011. № 2. С. 72-80].

Zuchiewicz W., Bubniak I.M., Rauch M., 1997. Wstępne wyniki badań nad spękaniami ciosowzmi w jednostce skibowej (skolskiej) Karpat Ukraińskich. Przeglad Geologiczny 45 (4), 408-413.
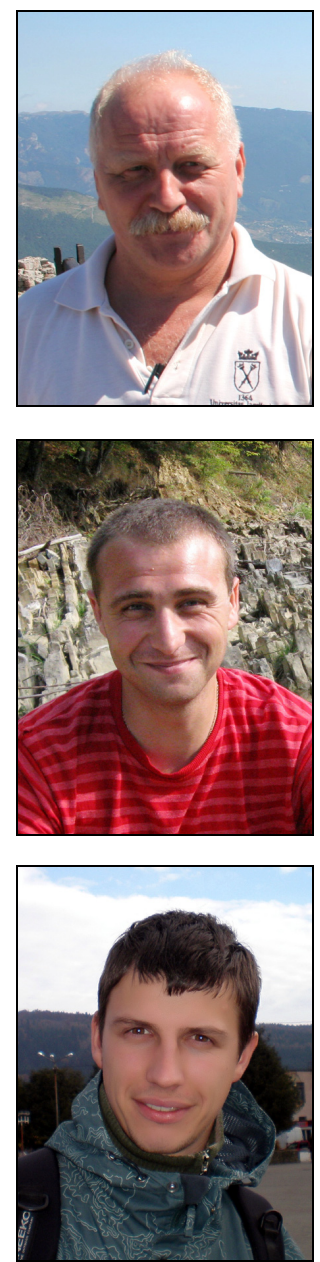

Бубняк Игорь Николаевич, канд. геол. наук, доцент

Львовский национальный университет имени Ивана Франко, геологический факультет

79005, Львов, ул. Грушевского, 4, Украина

凶e-mail: ibubniak@yahoo.com

Bubniak, Igor M., Candidate of Geological Sciences, Associate Professor

Department of Geology, Ivan Franko National University of Lviv

4 Grushevsky Street, Lviv 79005, Ukraine

$\bowtie$ e-mail: ibubniak@yahoo.com

Вихоть Юрий Михайлович, канд. геол. наук

Львовский национальный университет имени Ивана Франко, геологический факультет 79005, Львов, ул. Грушевского, 4, Украина e-mail: yuvik@ukr.net

Vikhot, Yury M., Candidate of Geological Sciences

Department of Geology, Ivan Franko National University of Lviv

4 Grushevsky Street, Lviv 79005, Ukraine

e-mail:yuvik@ukr.net

Накапелюх Михаил Владимирович, аспирант

Институт геофизики им. С.И. Субботина НАН Украины

03680, Киев, пр. Палладина, 32, Украина

e-mail: nmsol@ukr.net

Nakapelukh, Mykhail V., PhD Student

S.I. Subbotin Institute of Geophysics, NAS of Ukraine

32 Palladin Av., Kyiv 03680, Ukraine

e-mail:nmsol@ukr.net 